\title{
Articles
}

\section{MONETARY POLICY AND ASSET PRICES: WHAT ROLE FOR CENTRAL BANKS IN NEW EU MEMBER STATES?}

\author{
Jan Frait*, Luboš Komárek ${ }^{*}$
}

\begin{abstract}
:
The paper deals with the relationship between monetary policy and asset prices. Besides surveying the general discussion, it attempts to extend it to recent developments in the New Member States of the EU (NMS), namely the Czech Republic, Hungary, Poland and Slovakia (the EU4). After a brief description of the current macroeconomic situation in the NMS, the appropriate reaction of monetary policy to asset price bubbles is analysed and the main pros and cons associated with this reaction are summarized. Afterwards, the risks of asset market bubbles in the EU4 countries are evaluated. Since the capital markets are still underdeveloped and the real estate price boom seems to be a natural reaction to the initial undervaluation, the risks are viewed as rather small. The conclusion is thus that it is crucial for central banks in mature economies as well as in the NMS to conduct their monetary policies as well as their supervisory and regulatory roles in a way that does not promote the build-up of asset market bubbles. In exceptional times, central banks of small open economies must be ready to use monetary policy steps as a kind of insurance against the adverse effects of potential asset market bubbles.
\end{abstract}

Keywords: monetary policy, asset markets, central banking, New EU Member States

JEL Classification: E52, E58, G12

\section{Introduction, Current Developments in the New EU Member States}

The New Member States of the European Union (NMS) went through a successful stabilization process. With inflation and pressures for nominal appreciation of domestic currencies low (see Appendix), their central banks lowered short-term interest rates to his-

* Czech National Bank, Prague (jan.frait@cnb.cz)

** Czech National Bank, Prague and Prague School of Economics (lubos.komarek@cnb.cz orlubos_komarek@yahoo.com)

Authors note that everything contained in this paper represents their own views and not necessarily those of the Czech National Bank. However, all errors and omissions remain entirely the fault of the authors. The research behind this paper is supported by the Grant Agency of the Czech Republic within a project no. 402/05/2758. 
Figure 1

Monetary Policy Interest Rates in the EU4 (in \%)

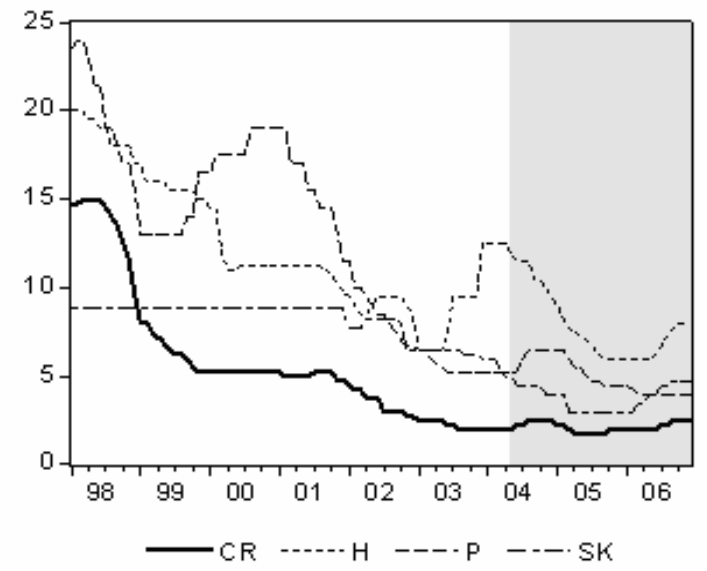

Note: $\mathrm{CR}=$ Czech Republic, $\mathrm{H}=$ Hungary, $\mathrm{P}=$ Poland, $\mathrm{SK}=$ Slovakia

Source: Eurostat, EU4 central bank web pages

Figure 2

Average Lending Rates in the EU4 (in \% p.a.)

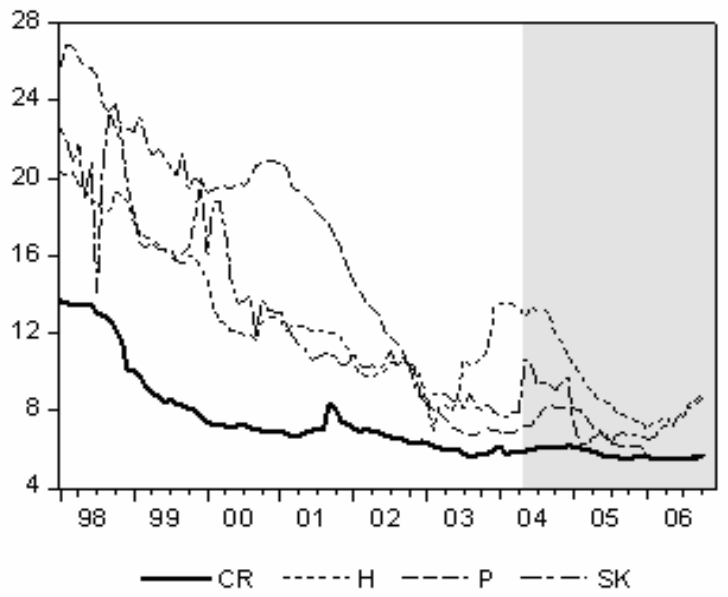

Note: $\mathrm{CR}=$ Czech Republic, $\mathrm{H}=$ Hungary, $\mathrm{P}=$ Poland, $\mathrm{SK}=$ Slovakia. The shaded area identifies membership in the EU.

Source: IMF-IFS CD-ROM 
torically low levels. Figure 1 shows the development of the monetary policy interest rates of the selected NMS, namely the Czech Republic, Hungary, Poland and Slovakia (EU4). There is a significant downward trend in all the rates, with the exception of the Polish rate during 2000 and the Hungarian policy swings during 2003. During the period under review, the lowest rates were always seen in the Czech Republic, which is the only economy with experience of a negative interest rate differential against ECB rates. ${ }^{1}$

Figure 2 presents the development of the average lending rates of the EU4 countries, which also slope down during the last decade, especially in Hungary, Poland and Slovakia. The Czech lending rates had already moved to very low levels by 1999 . Long-term nominal interest rates also went down sharply, thanks in part to expectations of euro adoption. In addition, restructured and privatized banks recently began to extend credit to the corporate sector and households again.

The combined effect can be seen mainly in a rapid credit expansion in the housing loans segment in the household sector, with yearly increases of between $30 \%$ and $50 \%$ in most countries (see Figure 3). There are fears that the mix of optimistic expectations and the credit boom in the environment of low interest rates may support investment of a speculative kind and create asset bubbles similar to those experienced by many developed economies in the past. And in the same way, the formation of these bubbles may not be accompanied by visible pressures for consumer price inflation, which is the main focus of central banks. And at the same time, the NMS have become part of the worldwide discussion on the impact of the low interest rate environment, high liquidity and easy availability of credit on asset markets and on the role of monetary policy in supporting and subsequently taming asset price inflation.

The NMS central banks thus now face the same questions as their counterparts in many developed countries: Are current monetary policies supporting the build-up of asset market bubbles? Should central banks incorporate asset prices into their policy decision-making processes and react to asset price inflation with interest rate changes? These particular questions have been the subject of a lively discussion in recent years among central bankers and academics in the US and many other countries. Our intention is to help to extend the discussion to the local scene, even though this may seem premature to at least some observers. For these reasons, we will focus mainly on the aforementioned EU4 economies. ${ }^{2}$

1 The Czech National Bank set its monetary policy rate (the 2-week REPO rate) below the European (ECB) level in three periods, 26 July 2002 - 6 December 2002, 31 January 2003 - 7 March 2003, and 29 April $2005-27$ October 2005. The negative interest rate differential was always 0.25 p.p., except for the period 1 November 2002 - 6 December 2002 (0.5 p.p.).

2 Skolková, Stiller and Syrovátka (2001) present the analysis of the role of asset prices in the monetary transmission mechanism with the empirical application to the Czech Republic. 
Figure 3

Household Credit Growth (average growth, in \%)

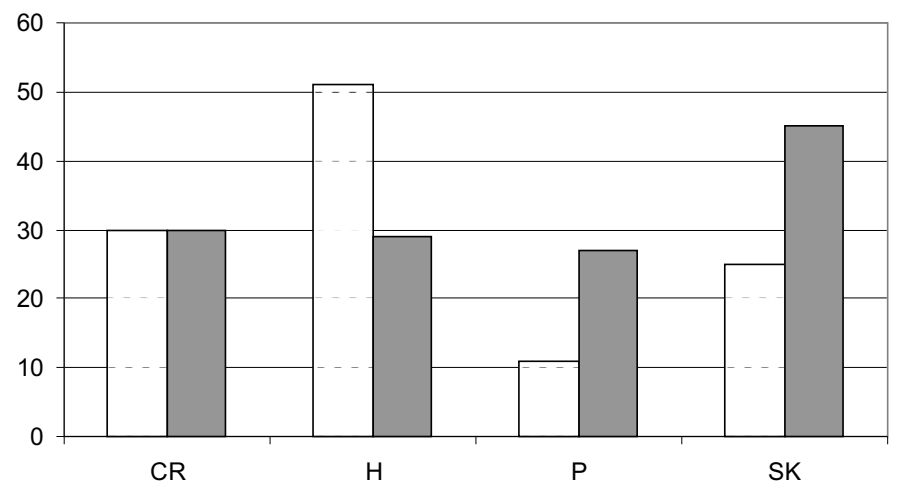

$\square$ 2001-2004 $\square 2004-2006^{*}$

*- only first two quarters of 2006.

Source: World Bank (2007)

\section{How Should Monetary Policy Respond to Asset Prices?}

\subsection{Importance of Asset Prices for Central Banks}

Whether monetary policy should actively seek to encourage asset price ${ }^{3}$ stability, or even whether it should seek to prevent or at least reduce asset price bubbles, really is one of the key current topics of debate among central bankers. Despite what the media sometimes say, hardly any central banker argues that central banks should completely ignore asset prices and focus only on consumer prices defined in terms of consumer price index (CPI) changes. As stressed by Bollard (2004), for example, economists agree that central banks should take asset prices into account, but they disagree on whether they should respond to asset price drifts.

Central banks automatically take asset price developments into account when setting monetary policy, even if formally they focus on price stability defined solely in terms of prices of consumption. This is primarily because asset price movements impact on CPI inflation and large movements in asset prices can have significant implications for CPI inflation. If prices of real estate, for example, are rising faster than inflation, people try to build more houses. To do so, they demand more building materials, putting pressure on the prices of those materials. In addition to that direct impact, asset price movements also feed into CPI inflation through the "wealth effect". As asset prices rise, people tend to feel wealthier. This can apply to any kind of asset, but in many countries

3 By asset price we mean the price of something bought to generate income or to be sold later on for a profit. Examples are physical assets such as real estate or collectables, and financial assets, such as shares, bonds, foreign exchange and other financial instruments. 
we see this mostly through house prices, due to the high proportion of household wealth associated with housing. The Czech Republic ranks among the countries where housing has a major share in household wealth, and at the same time, the share of net financial assets is relatively low and does not have a clear growth tendency. In countries with developed and broad stock markets, the wealth effect applies also to share prices.

Asset prices also feed through into spending and hence inflation in other ways. For example, asset price increases improve balance sheets, increasing the borrowing capacity of firms and individuals. Increases in net worth tend to increase the willingness of lenders to lend and borrowers to borrow, facilitating a general expansion in spending as well as an expansion in spending on investment in appreciating assets. Most of the time, asset and consumer prices roughly move together and asset prices present no major problem for monetary policy. There are, however, times when asset prices move well out of line with underlying economic fundamentals. Sometimes, asset prices can become disconnected from reasonable expectations of future earnings, resulting in speculative bubbles that cannot be justified by economic fundamentals. Sooner or later, speculative bubbles will burst. But the damage they can do to the economy can be huge. This brings us to the question of whether central banks should try to constrain asset price bubbles.

\subsection{Three Main Opinions on Asset Price Bubbles}

Economists have a variety of opinions on this question. We prefer to divide them into three groups. The first one comprises those who say that a central bank should pay attention to asset market developments, but cannot and should not try to constrain asset price bubbles on their own. Ben Bernanke, a Fed chairman, seems to serve as the speaker for this group. ${ }^{4}$ We will use his words to define the other two groups and explain his views on the issue. We will then question his views and explain why a more active approach may sometimes be justified.

Bernanke and Gertler $(1999,2001)$ or Bernanke (2002) suggest a very simple rule for central bank policy regarding asset market instability: Use the right tool for the job. Bernanke (2002) says that the Fed has two sets of responsibilities - maximum sustainable employment, stable prices and moderate long-term interest rates on the one hand, and the stability of the financial system on the other. To achieve that, the Fed has two sets of policy tools, policy interest rates and a range of powers with respect to financial institutions. By using the right tool for the job, he means that the Fed will do its best by focusing its monetary policy instruments on achieving its macro goals, while using its regulatory, supervisory and lender-of-last resort powers to help ensure financial stability.

Bernanke agrees that a central bank must monitor financial markets intensively and continuously. To the extent that a stock market boom causes higher spending on consumer goods and investments, it may indicate future inflationary pressures. A policy tightening might therefore be an appropriate reaction. But the goal of the reaction should be to contain the incipient inflation, not the stock market boom. A central bank cannot be an arbiter of security valuation. In other words, it should use monetary policy to target the

4 See also Gilchrist and Leahy (2002), Greenspan (2002) or Blinder and Reis (2005). The excellent summary why central banks should not burst asset bubbles is presented by Posen (2006). 
economy, not the asset markets. He believes that a far better approach is to use micro-level policies to reduce the incidence of bubbles and to protect the financial system against their effects.

To protect the financial system, the central bank should use its regulatory and supervisory powers instead. In particular, it should ensure, together with other financial sector regulators, that financial institutions and markets are well prepared for a large shock to asset prices. To achieve that, commercial banks must be well capitalized and well diversified and they should stress-test their portfolios against a wide range of scenarios. The central bank can also contribute to reducing the probability of boom-and-bust cycles by supporting more transparent accounting and disclosure practices and working to improve the financial literacy and competence of investors. And if a sudden correction in asset prices does occur, the central bank's first responsibility is to do its part to ensure the integrity of the financial infrastructure - in particular, the payment system and systems for settling trades in securities and other financial instruments. If necessary, the central bank should provide ample liquidity until the immediate crisis has passed.

Bernanke (2002) "sends" the advocates of a more active monetary policy response to asset prices into two broad camps, differing primarily in how aggressive they think the central bank should be in attacking bubbles. The first group favours a "lean-against-the-bubble" strategy. Its representatives ${ }^{5}$ agree that a central bank should take account of, and respond to, the implications of asset-price changes for its macro-goal variables. But also, according to this view, a central bank should try to gently steer asset prices away from the presumed bubble path. The theoretical arguments that have been made for the lean-against-the-bubble strategy are not entirely without merit. It seems that it may be worthwhile for a central bank to take out a little "insurance" against the formation of an asset-price bubble and its potentially adverse effects. Bernanke nevertheless believes that leaning against the bubble is unlikely to be productive in practice.

The second group comprises those preferring a more activist approach. Bernanke labels it "aggressive bubble-popping". ${ }^{\circ}$ Aggressive bubble-poppers would like to see a central bank raise interest rates proactively to eliminate potential bubbles. Bernanke views this particular approach as risky and dangerous. He supports this opinion by pointing to Federal Reserve policy in the 1920s. When interest rates peaked in August 1929, the economy was already slowing, though stock prices were still rather high. The Fed tried to prick the stock market bubble, but succeeded only in killing the economy. It seems to us that something similar may also have happened in Japan during the 1990s. The result was the lost decade of the Japanese economy. ${ }^{7}$

We agree that generally there are clear-cut arguments against an activist approach. First, a central bank cannot reliably identify bubbles in asset prices. This seems to be a crucial argument. What we do know is that the monetary policy response to an asset pri-

5 See, for example, Goodhart (1999), Bordo and Jeanne (2002), Borio and Lowe (2002) and Cecchetti (2002) et al who argue for more-proactive responses to asset price bubbles. The excellent summary why central banks should burst bubbles is presented by Roubini (2006).

6 Bernanhe nevertheless does not make reference to the proponents of this vieu. Also for us it is not easy to identify bubble-poppers among current economists.

7 The three main asset-price-bust episodes (the UK 1974, Japan 1992 and the USA 2001) were analysed, for example, by Ferguson, Jr. (2005). 
ce increase should depend on the source of the increase. And we agree that central banks should not react to asset prices unless they indicate changes in expected inflation. Unfortunately, it is rather difficult to know at any particular point in time whether the increase reflects fundamental improvements or excessively optimistic expectations. It is thus also difficult to know whether the asset price changes indicate improved productivity or higher expected prices. But on some occasions we can be quite sure that a bubble is on the way, because we simply cannot find any fundamentals behind the asset price drift.

Second, even if a central bank can identify bubbles, monetary policy does not possess appropriate tools for effective use against them. A small increase in the policy interest rate can only lead to a correspondingly modest decline in the likelihood or size of a bubble. It is unlikely that a small increase in short-term interest rates, unaccompanied by a significant slowdown of the economy, will induce speculators to modify their equity or real estate investment plans. Interest rates simply have limited power to affect the perceptions that move asset prices in the first place. To materially affect some asset prices, such as housing, interest rates would probably need to move by much more than would be required just to keep CPI inflation comfortably within the target range. Since interest rate changes affect not just house prices, but also the prices of most other assets, goods and services, there would be secondary, unintended consequences, with potentially serious consequences for the economy as a whole.

The third problem is the timing of the central bank's reaction. Once a central bank becomes sure that a bubble has emerged, it will probably be too late to act with interest rate hikes. These may instead conflict with other economic forces that have begun to act. Given the lag that we think applies between an interest rate move and its effect on the real economy, the risk is high that the policy moves would be wrongly timed and only make matters worse. If interest rates are high at the moment a bubble bursts, those high interest rates will still be affecting the economy two years on. This would make the landing harder.

Fourth, pursuing a separate asset price objective could mean having to compromise on the normal inflation objective. Seeking to stabilize rising house prices or an overheated stock market might mean having to force inflation lower than would otherwise be required. It might also mean greater variability in the real economy, interest rates and, potentially, the exchange rate.

\subsection{Is Bernanke Right?}

Does all this mean that Bernanke is right? We would say that in many ways yes. But we would also say that Bernanke ignores some important aspects. First, he seems to ignore the question of what to do if the bubble is emerging without any signs of inflationary pressures? Inflation measured in terms of consumer prices has not always signalled when imbalances in the economy have been building up. A strong expansion in credit and increasing asset prices have preceded almost all banking crises and the majority of deep recessions in countries around the world over the past one hundred years. In many cases inflation has at the same time been low and stable before the crisis.

A central bank reaction to growth in asset prices is believed to be appropriate only when signals exist that the economy may become overheated. However, the prevailing monetary policy models used to forecast inflation pressures often derive demand pres- 
sures (approximated by the output gap) from current inflation pressures. Given that, some signals that inflation pressures may increase in the more distant future may be ignored, especially if monetary policy horizons are too short.

Here we can provide a realistic scenario for a small open economy. It may arise when higher economic growth creates excessively optimistic expectations that lead to nominal appreciation of the domestic currency. In such a situation, very low inflation can prevail even under rapid credit growth and asset price acceleration for rather a long time. When the open inflation pressures finally appear, it may be too late for monetary policy to react. Forecasts of resource utilization and inflation can also be systematically inaccurate because the models and assessments used do not take account of the independent role that asset prices and debt can play. Also, as a result of structural changes, historical relationships may have changed, thus causing the central bank, for example, to come to incorrect conclusions about the output gap and potential growth. Nevertheless, central banks in increasing numbers compile financial stability analyses that should reveal these particular risks.

If these analyses identify the risk of a bubble emerging, responding is rather challenging. Nonetheless, the risks of the landing from the build-up and bursting of large asset price bubbles warrants taking some risks in an attempt to moderate the problem. There are cases where the asset price misalignment is sufficiently obvious that one can be confident enough to take the risk. Such situations are likely to be rare. And the risks may be considerable. In such a situation, tightening monetary policy may even lead consumer price inflation outside the target range. The central bank may be then blamed for squeezing growth from the economy. Nevertheless, by raising interest rates at an early stage when asset prices are starting to accelerate and before the expansion in credit has become too sharp, the central bank can indeed achieve somewhat lower inflation than is desirable in the short term, but may avoid a subsequent collapse in asset prices that could lead to considerably lower output and inflation in the longer term. And the somewhat tighter monetary policy than otherwise would be able to counter the over-optimistic pricing of financial assets and properties.

\subsection{Prudential Measures and Regulatory Features as a Solution?}

The use of regulatory and supervisory policies seems to be a natural reaction to a credit boom. In this sense, one of the last issues of the IMF World Economic Outlook (September $2005, \mathrm{p} .13^{8}$ ) argues that "in cases where house price inflation remains robust, a combination of moral suasion and if necessary prudential measures could help limit potential risks; over the long term, regulatory features - including those that potentially constrain supply - that may exacerbate price pressures need also to be addressed". However, it may be rather difficult to apply these micro-policies in reality.

Hilbers et al. (2005) provide an extensive list of such measures and features. Among the prudential measures, higher and differentiated capital, liquidity and reserve requirements, tighter loan classification and provisioning rules, dynamic provisioning (accounting for the phase of business cycle in calculating loan-loss provisions), stricter as-

8 The recommendations seem to build on the recent IMF Working Paper by Hilbers et al. (2005). 
sessment of collateral, or tighter eligibility criteria for certain loans are suggested. Supervisory measures include increasing disclosure requirements, closer inspection and periodic stress testing. Some countries have also applied administrative measures, such as bank-by-bank credit limits or mandatory credit rationing. During the last few years, some NMS applied measures to reduce credit dynamics in general and especially the part provided in foreign currencies. Among the measures, we can find special reserve requirements for foreign exchange liabilities, marginal reserve requirements based on credit growth, higher liquidity requirements foreign exchange liabilities, tighter capital requirements related to foreign currency lending, increasing the risk weighting of housing loans in capital, adequacy calculations.

Even the supporters of these measures are aware of their limited capacity and potential side effects. Hilbers et al. (2006) warn that these measures are not generally viewed as the "first best option". This applies especially to the "prudential measures", which should only be used when normal prudential measures (limits) do not work well. They argue that they should be used when there are financial stability risks or when there is room to bring a country's prudential and supervisory framework in line with international best practice ${ }^{9}$. That said, there are limits to what prudential policies can do in the absence of prudent fiscal policies or if monetary or fiscal regimes create incentives that encourage credit growth.

All this sounds very well, but the reality is often quite frustrating. In other words, various recommendations have often typical features of dispensing advice from on high advise of rather limited value. It is rather difficult to find examples of "prudential measures" or "regulatory features" working well. Can thus any measures of this kind be recommended to the Czech Republic or other NMS if a housing bubble emerges in the future and, at the same time, no problems with price stability exist? Probably not, and not only because the framework has already been strengthened and there is hardly any room for further tightening.

"Measures" are difficult to apply in reality due to competition from non-banking subjects and foreign banks and their local branches. The Basel II rules together with international accounting standards make the application of some nonstandard measures not so easy. High demand for credit is to some extent linked to international macroeconomic environment, macroeconomic approach should therefore be attempted first. Distorting administrative regulations surely have undesirable side effects. They are harming newcomers to the market, may create perverse incentives for banks to bias their lending into riskier ends of the lending spectrum. And last but not least, temporary success of "measures" can conceal real sources of problems.

The possibility of using prudential measures (in terms of anticyclical action) with the intention to address asset price bubbles was convincingly questioned by Bollard (2004). He finds administrative instruments to be blunt, harming newcomers to the market, distorting resource allocation and potentially depriving the private sector of sound investment opportunities. Prudential measures are unlikely to be very effective in add-

9 This sort of measure was used in the Czech Republic at the end of 1990s. The supervisory authority required banks to build up provisions to cover loss loans collateralized by real estate to $100 \%$ of their value over three years. The reason behind the measure was the evidence that during the 1990s banks were lending against rather overvalued real estate. 
ressing asset price cycles, either. The implementation of policy changes would take time, after which there would be potentially long and variable lags in the impact on asset prices. The use of such tools for macroeconomic purposes conflicts with the objective for which such tools were originally designed -i.e. financial stability. Indeed, the use of prudential regulation to moderate asset price cycles might backfire in some circumstances, creating perverse incentives for banks to bias their lending towards riskier ends of the lending spectrum, which in turn could reduce the stability of the financial system.

\section{Asset Markets and Risk of Bubbles in the NMS}

The restructuring and strengthening of financial sectors in the NMS has significantly increased access to external financing. This is facilitating the development of investment in various asset markets (the stock market, housing markets, the bond market). Despite remarkable progress, some of these markets are generally still thin and underdeveloped relative to mature economies. Nevertheless, this does not mean that the risks are relatively small. It may rather imply that it is more difficult to analyse these markets and detect potential imbalances. The difficulties are enhanced by incomplete data on the development of the asset markets in the NMS.

From the point of view of international investors, the foreign exchange and stock markets are the most interesting in the countries we are focusing on. Domestic investors usually predominate in real estate markets, with the exception of some major cities. Naturally, fast growth of domestic credit should have the potential to initiate bubbles in these particular markets. Unfortunately, the lack of reliable data on these markets in the NMS prevents us from providing comparisons and deriving conclusions. Besides looking at the EU4 economies, we will comment separately on the Czech asset market events. This is a natural reflection of specific knowledge and lower uncertainty regarding the data.

Despite rapid growth in lending to the private sector, the prudential indicators do not indicate a sizable increase in financial vulnerabilities in the banking systems of the EU4 countries and the NMS in general. Banks are well capitalized, they make hefty profits and the share of non-performing loans in their portfolios is declining. However, these are normally lagging indicators of banking problems. We must therefore pay attention to the potential risks of the rapid credit expansion. The implications of the rapid growth in lending to the private sector are very often discussed with the other EU4 central banks. We usually agree that the risks are relatively low or even nonexistent. The reason is quite simple - the low base phenomenon.

\subsection{Foreign Exchange Markets}

There is one asset price that is subject to direct reaction of the monetary policy of many central banks - the exchange rate. This reaction is given by the direct impact of the exchange rate on inflation. There might be disputes about whether or not foreign exchange is an asset, as well as whether or not monetary policy interest rates should react to exchange rate swings. In practice, however, the exchange rate is such an important variable that central banks, especially in small open economies, can hardly ignore it. Many 
central banks which apply a floating regime therefore adjust their interest rates or intervene when facing significant exchange rate changes.

The currencies of the EU4 countries became popular assets with international investors soon after the initial period of transition. The exchange rates of these currencies have been rather volatile at times, and some of the swings can be viewed as bubbles. Figure 4 shows the year-over-year changes in the EU4 currencies against EUR (lhs) and the changes in their nominal effective exchange rates (rhs) ${ }^{10}$, demonstrating a relatively high correlation of appreciation and depreciation waves.

Figure 4

Dynamics of Nominal Exchange Rates of the EU4 against EUR (y-o-y, in \%)
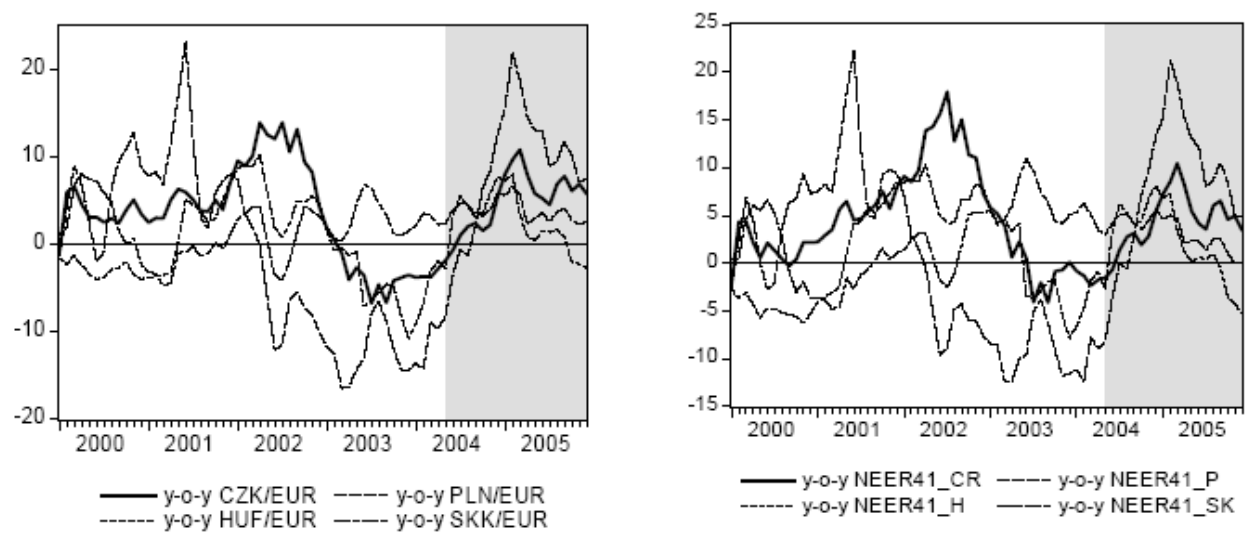

Note: $\mathrm{CZK}=$ Czech koruna, HUF = Hungarian forint, PLN = Polish zloty, SKK = Slovak koruna,

NEER41 = nominal effective exchange rate (41 main trading partners); (+) appreciation, (-) depreciation.

The shaded area identifies membership in the EU.

Source: Eurostat, IMF-IFS CD-ROM and authors' calculations

In the Czech Republic, a bubble-like situation was observed in 2002, when the CNB viewed the sharp appreciation of the koruna as unjustified by the fundamentals, labelled it a bubble and responded by interventions as well as interest rate cuts. The CNB explained its stance by the supposition that the appreciation was being caused by ill-perceived expectations of massive capital inflows due to privatization sales. The CNB thus tried to spread the correct information among market participants and, besides providing verbal information, had to ensure that the information content was credible. The fact is that the koruna eventually started to depreciate and is still rather weaker compared to its peak in July 2002 (the left-hand side of figures in the appendix). The right-hand side

10 The correlation between the year-over-year changes in the nominal bilateral exchange rate against EUR and the nominal effective exchange rate (41 main trading partners) for each particular country was very strong (lowest value of 0.82 for Slovakia, highest value of 0.98 for Poland). The correlation coefficient will be even higher if we use the NEER for less trading partners (the weight of the euro area countries will be higher). 
of this figure then shows what we can expect from a floating exchange rate regime, y-o-y appreciations by $10-15 \%$, followed by similar depreciation. PLN seems to be even more volatile than CZK, $20 \%$ up in 2001, then $15 \%$ down in 2003 and $20 \%$ up again in 2005. HUF also behaves like this, although the focus of the authorities on the exchange rate limits the fluctuations.

\subsection{Stock Markets}

Probably the first asset market bubble registered during the recent history of the Czech economy followed the voucher privatization process in 1993-1995. During this period, more than $60 \%$ of the population obtained shares in hundreds of firms and privatization funds. Despite the initial optimistic expectations - originating from the movement of speculative foreign capital, the bubble soon burst, since most of the shares lost value rapidly. The bust is captured, albeit only partially, by the decline in the official CNB-120 and PX-50 stock market indices ${ }^{11}$ (see Figure 5).

\section{Figure 5}

\section{Stock Market Indices in the Czech Republic (points)}

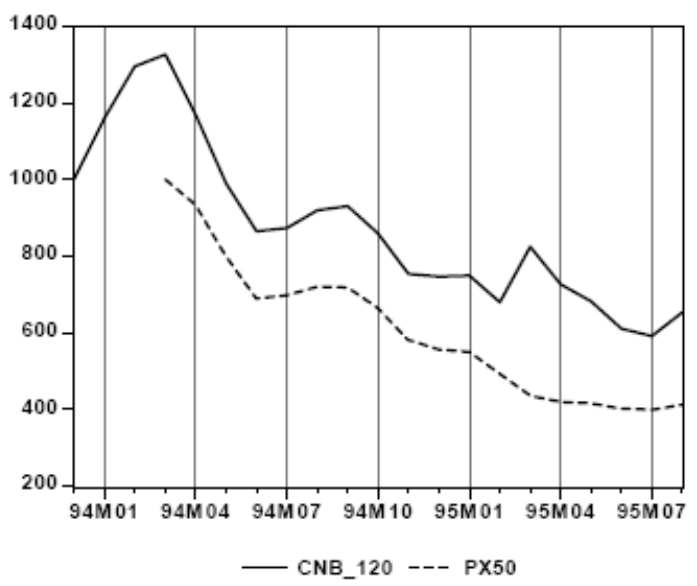

Note: CNB-120 = The Czech National Bank monitored trends in the share price movements of 120 issues traded on the Prague Stock Exchange. The component companies were chosen to reflect the economy as a whole and thus all industries ( 1 March $1995=1,000$ points); The PX50 consists of the most attractive domestic stocks traded on the Prague Stock Exchange in terms of turnover and market capitalization (5 April $1994=1,000$ points).

Source: www.cnb.cz

11 There were two waves of voucher privatization. The shares from the first one started to be listed in June and July 1993 (622 plus 333 titles) and those from the second one in March 1995 (674 titles). The CNB-120 index was published from the end of 1993 until 31 December 1999. Publishing of the PX-50 began in April 1994 and over time has changed in composition completely. The index is thus rather an imprecise description of the voucher shares' performance. Many shares in individual firms and privatization funds that were not included in the index lost value completely and were removed from trading. 
The allocation of shares among the population certainly had a kind of wealth effect, although it was probably not that strong. Hanousek and Tuma (2002) conclude that consumers behaved according to the permanent income hypothesis and demonstrate that only a minor part of the newly created assets actually led to an immediate increase in household consumption. The strong growth in domestic demand in the period was thus driven primarily by the corporate credit boom brought about by the loose financial constraint of the new banking sector. It was no surprise that the stock price bust was followed by a real economy bust later on (Frait, 2000). Monetary policy could not react much, because its objective at that time was to keep the exchange rate fixed.

How about the current stock markets in the EU4 countries? Recent sharp increases in stock exchange indices have already opened a debate on potential overvaluation due to purchases by foreign investors searching for higher yields. Figure 6 displays an almost ten-year history of stock exchange indices in the EU4 economies. The movements among the Czech, Hungarian and Polish capital markets have been particularly similar during the reporting period, with correlation indices of 0.64 (Czech against Hungarian), 0.48 (Czech against Polish) and only 0.08 (Czech against Slovak). ${ }^{12}$ Especially from the second half of 2003 onwards, we observe clear strong growth in all the indices.

Figure 6

Stock Market Indices in the EU4 $(1995 \mathrm{Q} 1=100)$

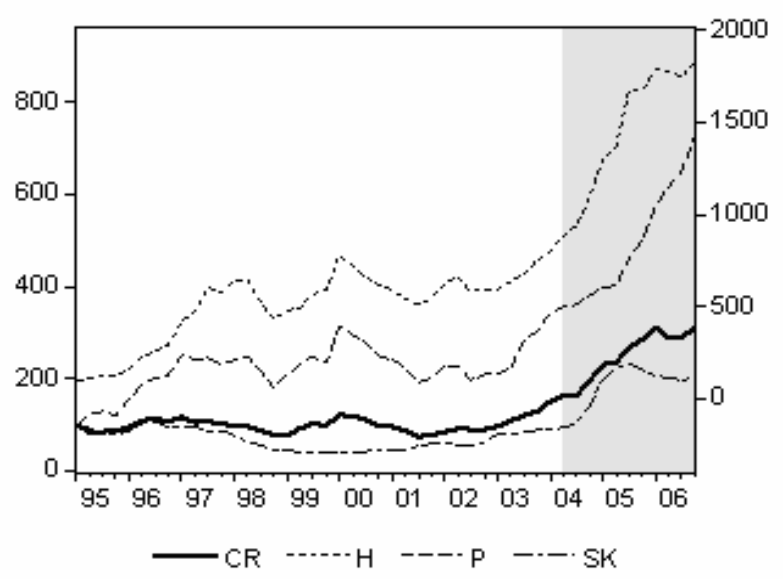

It is not our ambition to add to this particular debate. Instead, we have tried to find out to what extent the cycles in the EU4 stock exchanges have been associated with the corresponding business cycles. With this in mind, we calculate output gaps and stock exchange gaps by detrending the original series using the Band-Pass filter. ${ }^{13}$ The final outcomes are presented in Figure 7, which also confirms that the development of the

12 Both the very low correlation indices and the low level of market capitalization for Slovakia among all countries (see Figure 8) suggest that the Slovak capital market is very small and underdeveloped.

13 See, for example, Christiano and Fitzgerald (2003). 
Czech, Hungarian and Polish capital markets is in accordance with the development of real GDP. Such a relationship did not apply for any significant period in the Slovak case.

Figure 7

Output and Stock Exchange Gaps in the EU4 (in \%)
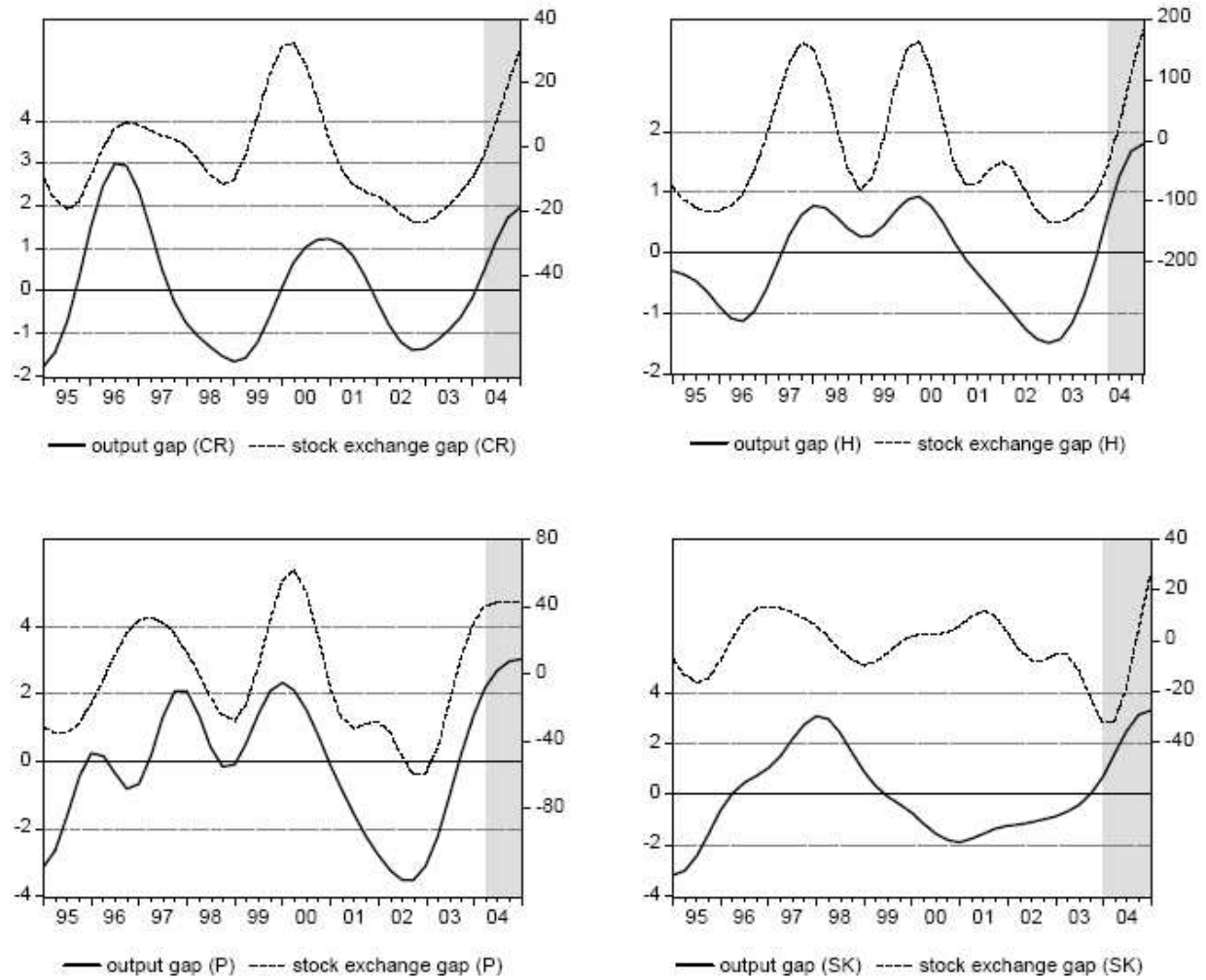

Note: Stock exchange gap on rhs; $\mathrm{CR}=$ Czech Republic, $\mathrm{H}=$ Hungary, $\mathrm{P}=$ Poland, $\mathrm{SK}=$ Slovakia.

The shaded area identifies membership of the EU.

Source: Eurostat, IMF-IFS CD-ROM and authors' calculations

The results suggest that stock prices generally reflect economic activity. Positive output gaps would in this case indicate future inflation pressures; the associated positive gap in stock prices would then provide no new piece of information. The reality is rather different. Standard monetary policy models base their estimations of the actual output gap more on the current state of inflation pressures than on the data on economic activity. Monetary policy models in many countries therefore do not incorporate stock market data. The eventual inclusion of the stock market depends on the country and the structure of the model used. However, the features of the stock markets in the EU4 countries (such as limited issuance of quoted equity and a low level of market capitalization) 
mean that their information content is of rather limited importance. Figure 8 confirms that the highest market capitalization is in the Czech Republic (since the second half of 2002) and that in all the EU4 countries the levels are increasing (strongly in the Czech Republic, Hungary and Poland, and slowly in Slovakia).

Figure 8

Market Capitalization in the EU4 (in \% of GDP)

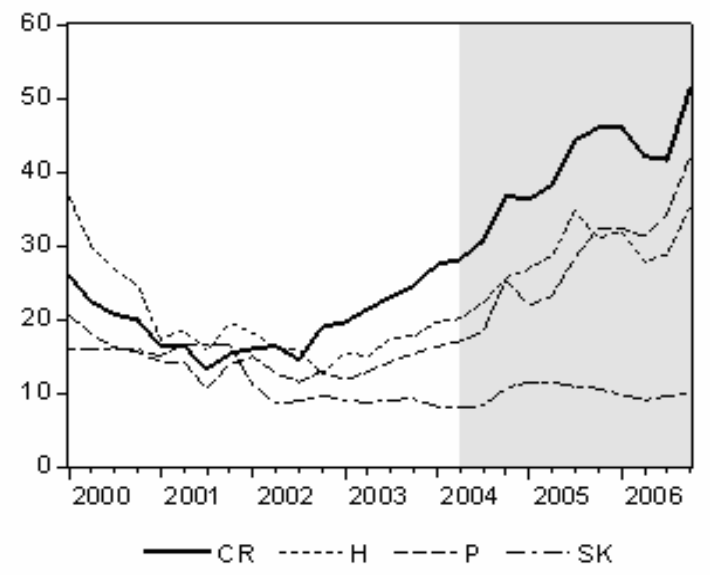

\subsection{Housing Market}

The growth rates of the mortgage markets in the NMS in recent years seem tremendous. However, the share of mortgages in GDP is still negligible compared to countries, such as the Netherlands or the United Kingdom. This is captured well by Figure 9, which plots growth in mortgage lending between 1998 and 2004 against the stock of mortgages as a percentage of GDP. All the EU4 countries are where they should be as catching-up economies. 
Figure 9

Housing Market - Growth in Mortgage lending against the Stock of Mortgages

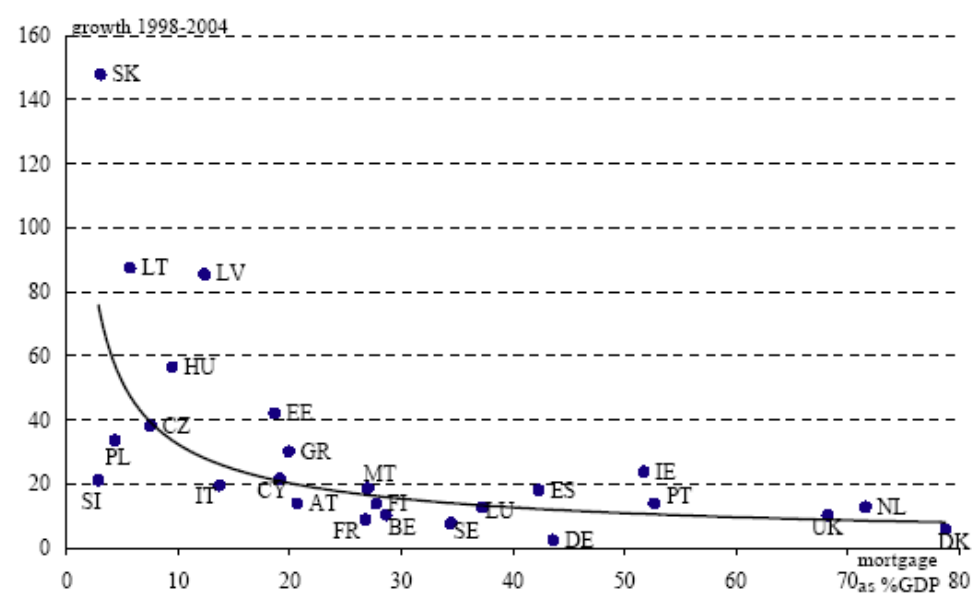

Source: $E C B$

Housing loans are also the fastest growing component of credit in the EU4 countries. How much should central banks be concerned with a potential house price bubble? It is difficult to say generally because we do not have comparable data series at our disposal. As far as the Czech Republic is concerned, the available data presented in Figure 10 can hardly be interpreted as a risk of a bubble. Despite remarkable dynamics in land prices, real estate prices seem to have been flat in the last two years. The price increases to date must be viewed mostly as movements towards more realistic values.

Figure 10

Real Estate and Land Prices in the Czech Republic and Prague $(1999$ Q1 $=100)$
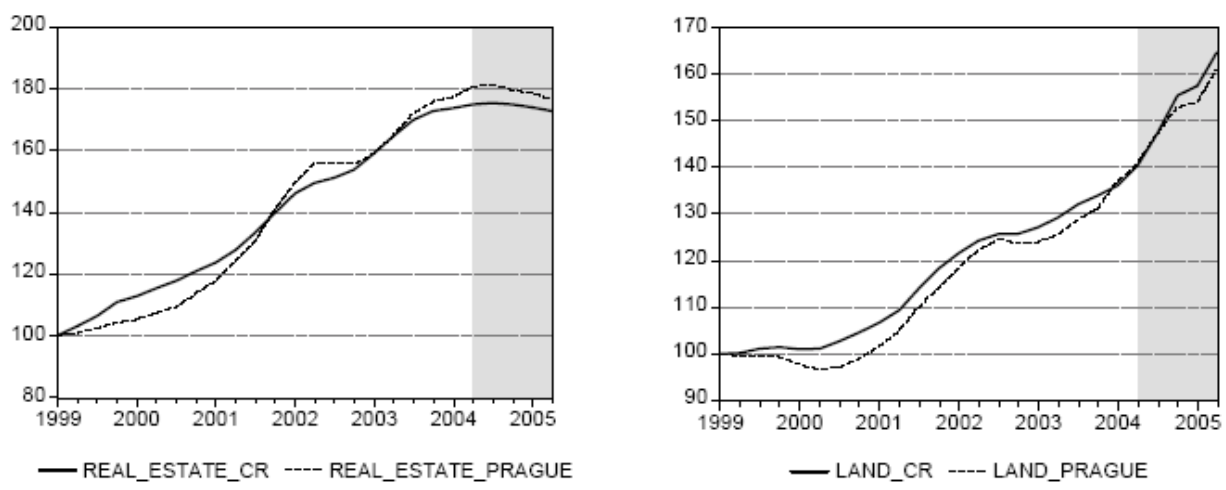

Note: $C R=C z e c h$ Republic. The shaded area identifies membership in the EU.

Source: Czech Statistical Office and internal calculation of the Czech National Bank 


\subsection{Global Liquidity, Housing Loans and Real Estate Prices}

In the last few years, low nominal and real interest rates plus high global liquidity have been reflected in many countries by relatively high growth in credit and money supply. At the same time, many countries have experienced a real estate price boom. There is an interesting discussion among economists about whether money supply dynamics is causing real estate prices to rise or whether increased money creation is only a natural consequence of increased money demand due to the wealth effect of real estate price developments. This particular discussion is important for assessing the inflationary potential of the current money supply dynamics. If it is a consequence of the above-defined wealth effect, the inflation risk may be low, since once the real estate price growth slows down, demand for money will slow down too. Money supply growth rates would then tend to fall to much lower figures.

Of course, money supply growth may be adding to the real estate price expansion. In many countries, the credit growth is apparently associated with the extension of housing loans. We can see numerous countries with real estate price growth of more than $10 \%$ annually in recent years (France, Greece, Ireland, Italy, Spain, the United Kingdom, South Africa, New Zealand, the USA and Australia). According to the Economist (which compiles representative indices of real estate prices), relative to income, real estate prices peaked historically in 2004 in the USA, Australia, the United Kingdom, France, Ireland, the Netherlands, New Zealand and Spain ${ }^{14}$. In some countries, structural changes in financial markets seem to be behind this. In some countries of the euro area, a fall in nominal interest rates to the German level acted as a booster. We plot credit growth and real estate prices in Figure 11. We can see a relatively strong correlation, but we cannot assign a causal relation to it.

14 Currently we are seeing flat or even declining real estate prices in some of these countries. 


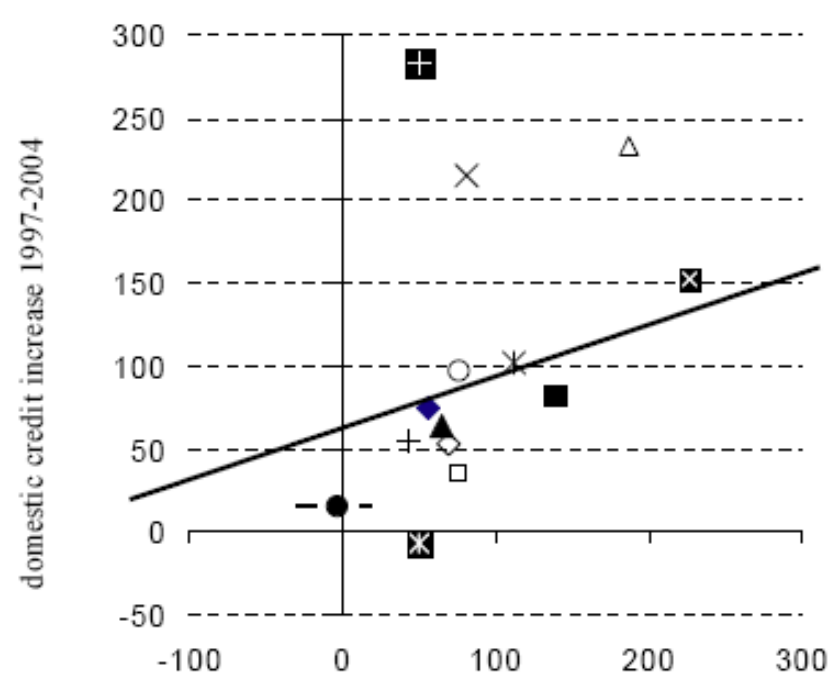

domestic house prices increase 1997-2004 $\bullet$ New Zealand

- UK

$\Delta$ USA

$\times$ Sweden

* Australia

† Denmark

+ Canada

- Sw itzerland

- Japan

X SAR

$\square$ France

$\Delta$ Ireland

$\diamond$ Italy

- Netherlands

- Germany

* Belgium

Note: DOMESTIC_CREDIT $=65.96+0.088^{*}$ HOUSE_PRICES ${ }^{15}$

Source: authors' calculations based on IMF IFS and Economist indices (Economic Intelligence Unit database).

Real estate market trends should be of concern to central banks in countries where real estate prices have a strong impact on consumer spending. This applies primarily to economies where mortgages with floating interest rates prevail and with widespread "mortgage equity withdrawal" (borrowing that is secured by housing stock but not invested in it) ${ }^{16}$. And these are the same countries that are prone to real estate market bubbles associated with periods of low real interest rates and strong credit expansion.

A dominant view among central bankers is one that does not associate actual growth in real assets with inflation, because it does not influence the value of money expressed in goods and services. The reason is simple - future inflation should already be embodied in real asset prices. These can be expressed as the discounted value of future incomes from holding the assets. The discount factor for real asset valuation can be approximated by the real interest rate. If central banks base their decisions on estimated future inflation, they in some way stabilize the real interest rate. Prices of real assets then do not constitute a new piece of information. The application of this particular logic to real

15 A non-linear relationship might exist, but this will not completely change our finding that higher house prices cause higher domestic credit.

16 One of the examples is the Netherlands, where a decline in real estate price growth from $20 \%$ in 2000 to zero in 2003 led to a drop in consumption and to recession. It hardly makes sense to blame the euro. 
estate prices is nevertheless questionable. A number of activities linked to real estate influence the value of money in terms of goods and services. Changes in real estate prices then have a direct impact on domestic demand via the wealth effect or via the ability to borrow against collateral. Real estate price change can thus, under some circumstances, be viewed to some extent as new information for policymakers. As far as the EU4 countries are concerned, the current credit dynamics do not seem to pose risks to asset markets and financial sectors. For their monetary policies, "benign neglect" thus still makes sense.

\section{Conclusion}

Central banks have tremendous difficulties in identifying and taming asset price bubbles. Neither monetary policy instruments nor supervisory and regulatory measures can be of much help when a bubble occurs. It is therefore crucial for a central bank to conduct its monetary policy as well as its supervisory and regulatory roles in a way that does not promote the build-up of asset market bubbles. Monetary policy must therefore be maximally forward-looking. Central banks should not be thinking only in terms of the next two years, as is the standard for monetary policy models. Given the potentially long-term nature of asset price misalignments, analyses of financial stability supporting monetary policy-making must look at longer horizons while applying a risk management approach to financial market developments. In exceptional times, central banks of small open economies must be ready to use monetary policy steps as a kind of insurance against the adverse effects of potential asset market bubbles. The reaction to other sorts of bubbles should depend on the particular conditions in the given time. 


\section{APPENDIX}

Inflation and Nominal Exchange Rates in the EU4
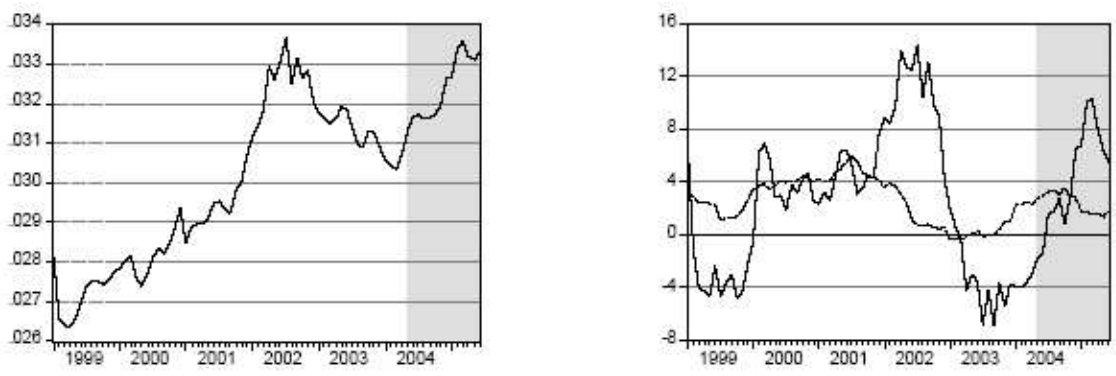

$$
\text { - EUR_CZK }
$$

- y-o-y_CZK --- Infation_CR
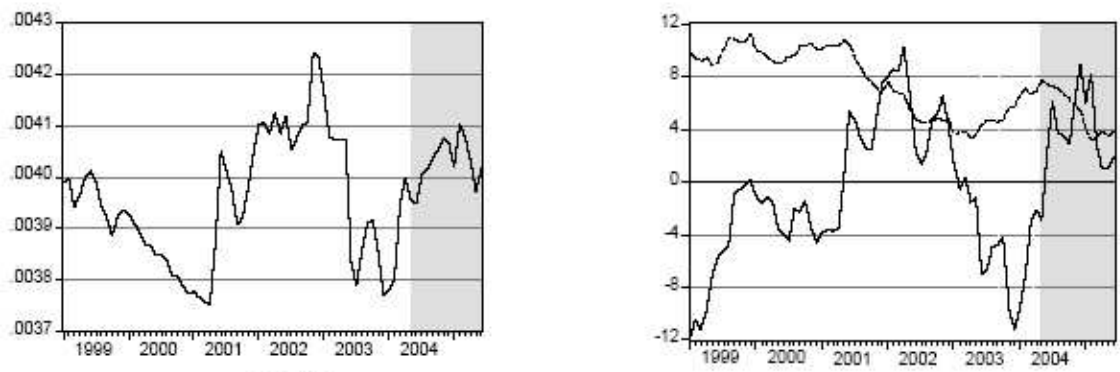

- EUR_HUF

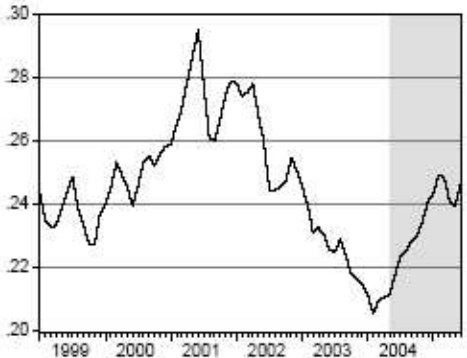

-yo-y_HUF - - Inflation_H

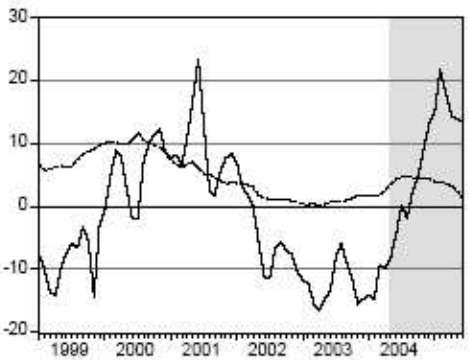

- EUR_PLN

- y-o-y_PLN -- inflation_P

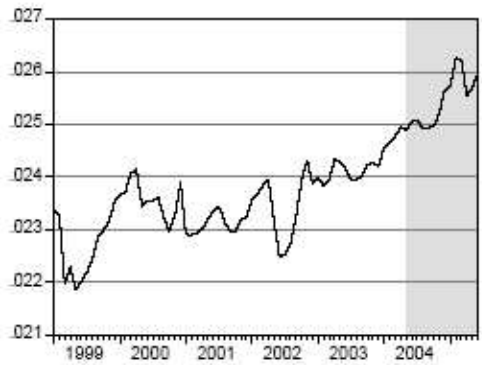

- EUR_SKK

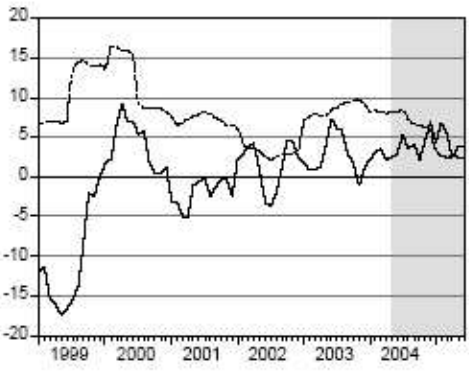

- y-o-y_SKK - hflation_SK

Note: rhs, (+) appreciation, (-) depreciation. The shaded area identifies membership in the EU.

Source: Eurostat, IMF-IFS CD-ROM and authors' calculations 


\section{References}

Bernanke, B., Gertler, M. (1999), "Monetary Policy and Asset Price Volatility." Federal Reserve Bank of Kansas City Economic Review, Fourth Quarter, pp. 17-51.

Bernanke, B., Gertler, M. (2001), "Should Central Banks Respond to Movements in Asset Prices?" American Economic Review, 91(2), May, pp. 253-257.

Bernanke, B. (2002), "Asset-Price "Bubbles" and Monetary Policy." Remarks before the New York Chapter of the National Association for Business Economics, New York, October 15, 2002, http://www.federalreserve.gov/boarddocs/speeches/2002/20021015/default.htm.

Blinder, A. S., Reis, R. (2005), "Understanding the Greenspan Standard." CEPS Working Paper No. 114, September 2005.

Bollard, A. (2004), "Asset Prices and Monetary Policy." An Address to the Canterbury Employers' Chamber of Commerce, Christchurch, 30 January 2004. BIS Review, No. 7, 2004, http://www.bis.org/review/r040206f.pdf.

Bordo, M., Janne, O. (2002), "Monetary Policy and Asset Prices, Does Benign Neglect Make Sense?" International Finance, December 2002, 5(2), pp. 139-64.

Borio, C., Lowe, P. (2002), "Asset Prices, Financial and Monetary Stability, Exploring the Nexus." Bank for International Settlements (Basle, Switzerland) Working Paper No. 114.

Cechetti, S., Genberg, H., Wadhwani, S. (2002), "Asset Prices in a Flexible Inflation Targeting Framework." NBER Working paper series. National Bureau of Economic Research, No. 8970.

Christiano, L.J., Fitzgerald, T. J. (2003), "The Band Pass Filter." International Economic Review, 44(2), pp. 435-465.

Ferguson, R. W. Jr. (2005), "Recessions and Recoveries Associated with Asset-Price Movements, What Do We Know?" The Real Estate Roundtable, Washington, DC, January 27, 2005, http://www.federalreserve.gov/BoardDocs/speeches/2005/20050112/default.htm.

Frait, J. (2000), "Economic Transition in the Czech Republic, A Real Success?" in Kaluyzhnova, Y., Lynch, D., Tucker, N., eds., The Euro-Asian World, A Period of Transition. Macmillan Press (UK) \& St. Martin Press USA, pp. 116-140.

Gilchrist, S., Leahy, J. V. (2002), "Monetary Policy and Asset Prices." Journal of Monetary Economics, 49(1), pp. 75-97.

Goodhart, Ch. (1999), "Central Bankers and Uncertainty." Bank of England Quarterly Bulletin, 39(1).

Greenspan, A. (2002),"Opening Remarks," in Rethinking Stabilization Policy. Kansas City, MO, Federal Reserve Bank of Kansas City, pp. 1-10.

Hanousek, J., Tůma, Z. (2002), "A Test of the Permanent Income Hypothesis on Czech Voucher Privatization." Economics of Transition, No. 10, pp. 235-254.

Hilbers, P., Otker-Robe, I., Pazarbasioglu, C., Johnsen, G. (2005), "Assessing and Managing Rapid Credit Growth and the Role of Supervisory and Prudential Policies." Washington, DC, International Monetary Fund, Working Paper No. WP/151/05, July 2005.

Hilbers, P., Otker-Robe, I., Pazarbațýoglu, C. (2006), "Going too Fast?" Finance \& Development, 43(1), March, pp. 42-47.

International Monetary Fund (2005), "IMF World Economic Outlook." Washington, DC, September 2005.

Posen, A. S. (2006), "Why Central Banks Should Not Burst Bubbles." International Finance, 9(1), pp. 109-124.

Roubini, N. (2006), "Why Central Banks Should Burst Bubbles." International Finance, 9(1), pp. 87-107.

Skolková, M., Stilller, V., Syrovátka, J. (2001), “Úloha cen aktiv v měnovém transmisním mechanismu." Finance a úvěr, 51(9).

Srejber, E. (2004), "What Role Do Asset Prices and Credit Play in Monetary Policy?" Remarks for Adam Smith Seminar, Thun, Switzerland, 30 June 2004, http://www.bis.org/review/r040713h.pdf.

World Bank (2007), Credit Expansion in Emerging Europe: A Cause For Concern? EU8+2Regular Economic Report, PART II: Special Topic January 2007. 